\title{
THE MODEL OF PRODUCT QUALITY, PROMOTION, PRICE, AND PURCHASE DECISIONS
}

\author{
Erna S.Imaningsih dan Saiful Rohman \\ Universitas Mercu Buana \\ (esofriana@gmail.com)
}

\begin{abstract}
Abstrct: The development of increasingly complex consumer needs and increasingly sharp market competition causes HONDA must be able to compete to show the benefits of its products and grab the attention of the consumers, one way to do it is to create a new product class SUV Medium namely HONDA H-RV. Consumers who will take the decision in choosing HONDA H-RV will consider various things in buying. Considerations are influenced by product quality, price, and promotion. Analytical techniques using validity test, Realibility test, multiple linear regression, $t$ test, $F$ test with SPSS 23.0 tool. based on the results of statistical calculations with linear regression analysis can be shown by the regression equation $\mathrm{Y}=1,956+0,462 \mathrm{X} 1+0,239 \mathrm{X} 2+$ $0,256 \mathrm{X} 3+\mathrm{e}$ from regression equation known that product quality, price, and promotion have positive influence to purchasing decision. The result of calculation coefficient of determination equal to 0,673 , it shows that product quality, price, and promotion are able to explain purchase decision equal to $67,3 \%$. While the remaining $32.7 \%$ is explained by other variables that are not observed. Based on the result of data analysis, it can be concluded that there is positive influence of product quality, price, and promotion to decision of purchase of HONDA H-RV and have strong correlation level, it means if product quality, price, and promotion is increased it will result in high purchase decision .
\end{abstract}

Keywords: Product Quality, Price, Promotion, Purchase Decision

\begin{abstract}
Abstrak: Perkembangan kebutuhan konsumen yang semakin kompleks dan persaingan pasar yang semakin tajam enyebabkan HONDA harus dapat bersaing memperlihatkan keunggulan produknya dan merebut perhatian konsumen salah satu caranya dengan membuat produk baru dikelas SUV Medium yaitu HONDA H-RV. Konsumen yang akan mengambil keputusan dalam memilih HONDA H-RV akan mempertimbangkan berbagai hal dalam membeli. Pertimbangan itu antara lain dipengaruhi oleh kualitas produk, harga, danpromosi. Teknik analisa yang menggunakan Uji validitas, Ujirealibilitas, regresi linier berganda, Ujit, Uji F dengan alat bantu SPSS 23.0. berdasarkan hasil perhitungan statistic dengan analisis regresi linier dapat ditunjukkan dengan persamaan regresi $\mathrm{Y}=1,956+$ $0,462 \mathrm{X}_{1}+0,239 \mathrm{X}_{2}+0,256 \mathrm{X}_{3}+\mathrm{e}$ dari persamaan regresi diketahui bahwa kualitas produk, harga, dan promosi memiliki pengaruh yang positif terhadap keputusan pembelian. Hasil perhitungan koefisien determinasi sebesar 0,673 hal ini menunjukkan bahwa kualitas produk, harga, dan promosi mampu menjelaskan keputusan pembelian sebesar 67,3\%. Sedangkan sisanya $32,7 \%$ dijelaskan oleh variabel lain yang tidak diamati. Berdasarkan hasil analisa data dapat disimpulkan adanya pengaruh positif kualitas produk, harga, dan promosi terhadap keputusan pembelian HONDA H-RV dan memiliki tingkat keeratan hubungan yang kuat, hal ini berarti apabila kualitas produk, harga, dan promosi ditingkatkan maka akan mengakibatkan keputusan pembelian yang tinggi.
\end{abstract}

Kata Kunci: KualitasProduk, Harga, Promosi, KeputusanPembelian 


\section{INTRODUCTION}

The development of the automotive world is currently running rapidly, creates an increasingly fierce competition. This requires manufacturers to be more sensitive, critical, and reactive to existing changes, both political, socio-cultural, and economic. Terms that must be met by a company in order to achieve success in the competition is trying to reach the goal to create and retain customers. To achieve that purpose, each company must strive to produce and deliver goods and services desired by the consumer at a reasonable price. Thus, every company must be able to understand the viability of the company as an organization that seeks to meet the needs and desires of consumers is highly dependent on consumer behavior (Tjiptono, 2008).

Indonesia is one of the countries with the largest number of car production with position number fifteen. The development of car production in Indonesia continues to develop in 2011 to 2015 which can be seen from the picture below

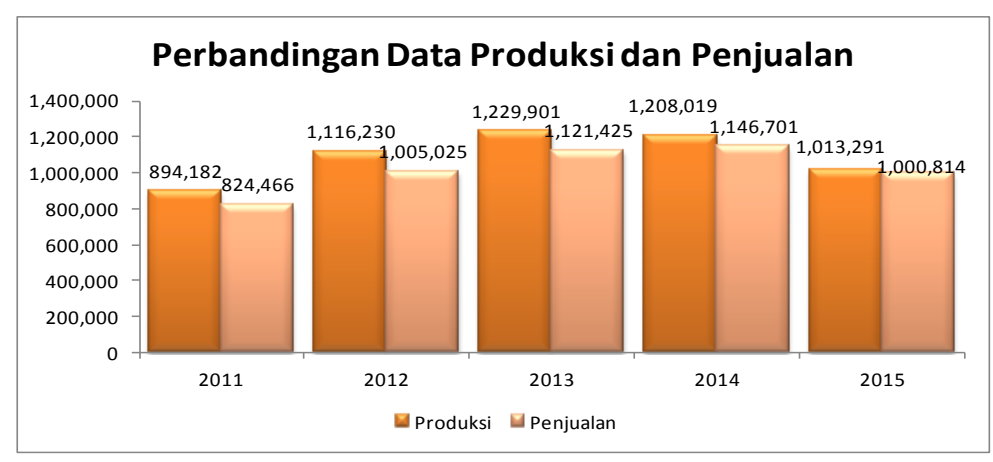

Figure 1. Comparison of Production and Sales Data

Source: Internal Astra company that is general

HONDA became one of the three largest automotive companies with sales in 2015 to reach 152,978 units or with $15.3 \%$ share, although the growth in automotive is likely to continue to decline every year. It can be seen in comparison chart below.

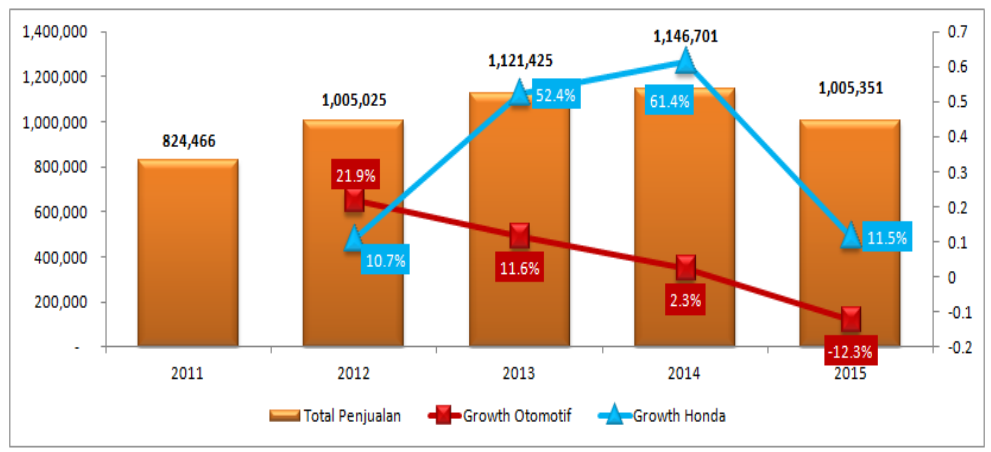

Figure 1. Comparison of Production and Sales Data

Source: Internal Astra company that is general 
One of HONDA's sales contribution is from segmentation of MEDIUM SUV HONDA although it newly dives into this segmentation, but it manages to seize the existing market share. It is seen in the Table below.

Table 1. Sales and Market share SUV Medium year 2011-2015

\begin{tabular}{|c|c|c|c|c|c|c|c|c|c|c|c|}
\hline \multirow{2}{*}{\multicolumn{2}{|c|}{ VOL }} & \multicolumn{2}{|c|}{2011} & \multicolumn{2}{|c|}{2012} & \multicolumn{2}{|c|}{2013} & \multicolumn{2}{|c|}{2014} & \multicolumn{2}{|c|}{2015} \\
\hline & & VOL & MS (\%) & VOL & MS (\%) & VOL & MS (\%) & VOL & MS (\%) & VOL & MS (\%) \\
\hline \multirow[t]{8}{*}{ SUV MEDIUM } & TOYOTA RUSH & 21,206 & $44.8 \%$ & 31,592 & $47.8 \%$ & 31,179 & $47.9 \%$ & 29,460 & $51.1 \%$ & 26,557 & $33.8 \%$ \\
\hline & DAIHATSU TERIOS & 19,801 & $41.8 \%$ & 22,995 & $34.8 \%$ & 25,162 & $38.6 \%$ & 18,274 & $31.7 \%$ & 13,607 & $17.3 \%$ \\
\hline & HONDA HR-V & & $0.0 \%$ & & $0.0 \%$ & 1 & $0.0 \%$ & & $0.0 \%$ & 30,752 & $39.2 \%$ \\
\hline & FORD ECOSP & & $0.0 \%$ & & $0.0 \%$ & & $0.0 \%$ & 3,326 & $5.8 \%$ & 3,614 & $4.6 \%$ \\
\hline & MITSUBISHI OUTLANDER & & $0.0 \%$ & 3,071 & $4.6 \%$ & 4,805 & $7.4 \%$ & 4,304 & $7.5 \%$ & 2,680 & $3.4 \%$ \\
\hline & MAZDA JUKE & 4,847 & $10.2 \%$ & 7,721 & $11.7 \%$ & 3,276 & $5.0 \%$ & 1,929 & $3.3 \%$ & 972 & $1.2 \%$ \\
\hline & OTHERS & 1,506 & $3.2 \%$ & 695 & $1.1 \%$ & 709 & $1.1 \%$ & 311 & $0.5 \%$ & 337 & $0.4 \%$ \\
\hline & SUV MEDIUM & 47,360 & $100.0 \%$ & 66,074 & $100.0 \%$ & 65,132 & $100.0 \%$ & 57,604 & $100.0 \%$ & 78,519 & $100.0 \%$ \\
\hline
\end{tabular}

Based on Table 1. HONDA H-RV which is a new product in the Medium SUV segmentation, surprisingly this product is getting a lot of devotees. In its first year HONDA H-RV successfully closed 30,752 units of sales and directly became market leader with $39.17 \%$ market share, beating Toyota Rush with sales of 26,557 units and market share of $33.82 \%$.

Kotler and Armstrong (2008) define marketing as follows: Marketing is a social and managerial process that allows individuals and groups to get what they need and want through the creation and designation of mutual products and value with others. From this understanding it appears that the company explores what is requested and needed by consumers and then trying to develop products that will satisfy the conumersthat make them have many alternative choices of products before making a decision to buy a product offered. In further developments, the consumer becomes a key determinant factor for the success or failure of a company in marketing its products. Companies must be able to recognize in advance what will be the needs and expectations of consumers today and the future. This is where it takes a marketing manager who has a thorough knowledge of consumer behavior in order to provide a good market definition to keep up with these constant changes, and to design the right mix of marketing. Based on the background, the authors see that there is an unusual phenomenon that occurs when the automotive market conditions tend to decline, especially in the segment of SUV Medium, but HONDA HR-V in the first year of the successful launch became market leader previously occupied TOYOTA RUSH.

Problem Research Formulation: (1) Does the product quality significantly influence the purchase decision?; (2) Does the price have a significant effect on purchasing decisions?; (3) Does promotion have a significant effect on purchasing decisions?

\section{REVIEW OF LITERATURE}

Product Quality Theory. Kotler and Armstrong (2008) stated that "Product quality is the ability of a product to perform its functions which include durability, reliability, accuracy, ease, operation and improvement as well as other attributes". When a product has been able to perform its functions, it can be regarded as a good quality product. 
According to Kotler (2008), most products are provided on one of four quality levels: low quality, medium average quality, good quality and excellent quality. Some of the above attributes can be measured objectively. However, from the point of marketing, quality must be measured from the buyer's perception about the quality of the product. Kotler \& Armstrong (2008) say that product quality is a potential strategic weapon to beat competitors. So only the company with the best product quality will grow rapidly, and in the long run the company will be more successful than the other company.

Theory of Price. Prices according to Kotler and Armstrong (2008) are the sums exchanged for a product or service. Furthermore, prices are the amount of value that consumers redeem for the amount of benefits by owning or using a good or service. Price is the thing that consumers pay attention to when making a purchase. Some consumers even identify prices with value. According to Swastha (2007), the price is a sum of money (plus some items if possible) needed to obtain some combination of goods and services.

The price dimension of this study refers to Elliot (2012), which according to Elliot (2012) the price is a matter related to the valuation of the customer regarding a price of the product itself. Price in the framework of the above thought is measured by three dimensions, namely: (1) Price Estimate, which is the customer's assessment of the price range of a product by looking at the quality of a product, as well as the suitability of the customer's wishes. (2) Conformity of the manufacture, that is, the customer's assessment of the product price which is seen from the aspect of the benefits to be gained. (3) Price fairness, that is, the customer's assessment of the price of the product with the affordability of price and price fairness when compared to similar products and different manufacturers.

Promotional Theory. According to Tjiptono (2008,) sales promotion is a form of direct persuasion through the use of various incentives that can be arranged to stimulate the purchase of products immediately and increase the amount of goods purchased customers. The dimensions of product quality in this study refer to Kotler, where according to Kolter (2008) the dimensions of the promotion mix are as follows: (1) Advertising, (2) Sales Promotion, (3) Public Relations and Publicity ( Public Relation and Publicity), (4) Personal Sales (Personal Selling), (5) Direct Marketing.

Theory of Purchase Decision. According to Philip Kotler (2009), the definition of a purchase decision is a process of problem solving consisting of analyzing or recognizing needs and wants, searching information, valuing sources of selection on alternative purchases, purchasing decisions and behavior after purchase.

According to Philip Kotler (2009) there are five stages in the buying decision process, where the buying phases that occur are as dimensions of this variable. It is seen in Figure 2. below.

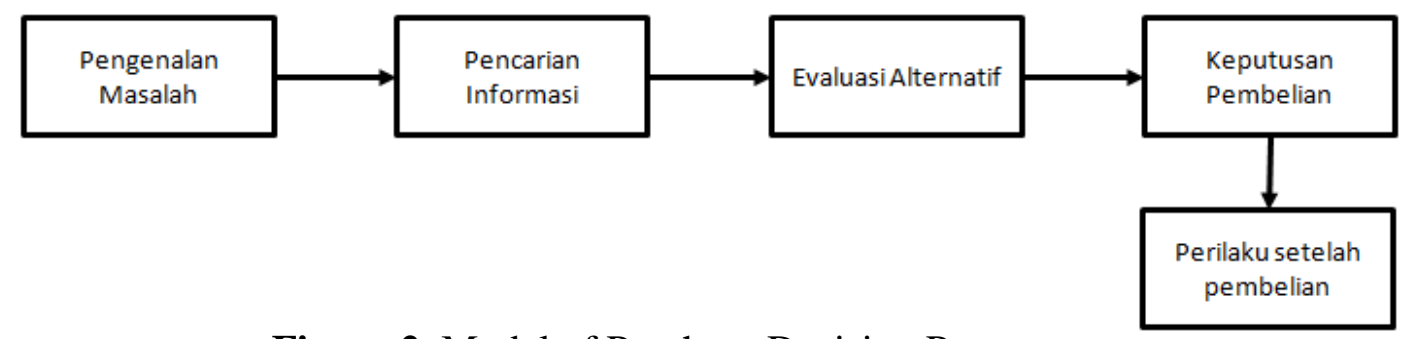

Figure 2. Model of Purchase Decision Process 


\section{Conceptual And Hypotheses Conceptual Framework}

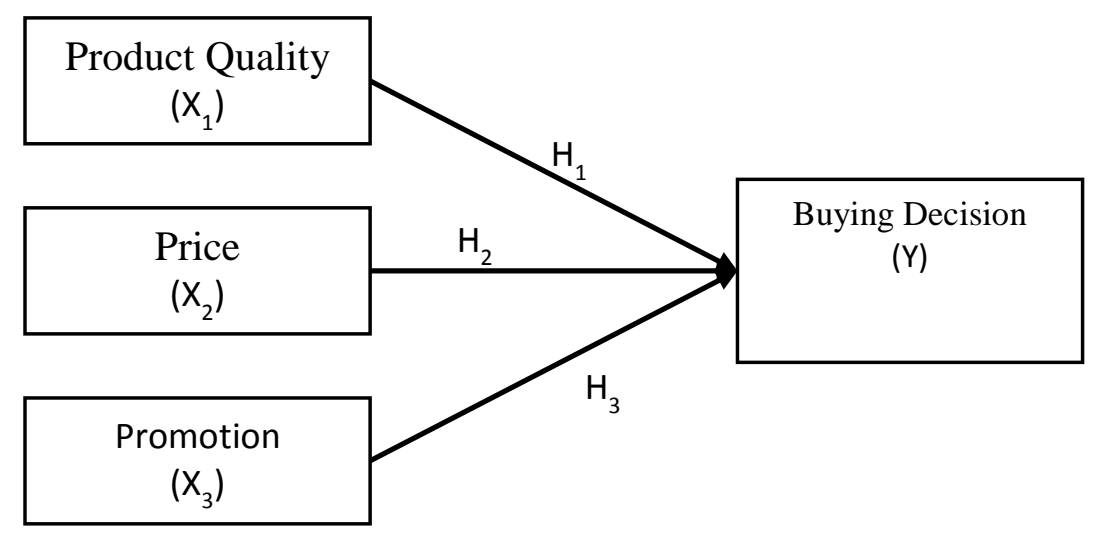

Figure 3. Conceptual Structures

H1: Product quality has significant effect on purchasing decision.

$\mathrm{H} 2$ : Price has significant effect on purchasing decision.

H3: Promotion has a significant effect on purchasing decisions

\section{RESEARCH METHOD}

Research Design. In the preparation of this study the researchers used the method of causal analysis. Causal is a causal relationship. The approach taken in this research is quantitative approach. According to (Noor, 2011), quantitative approach is a method to test certain theories by examining the relationship between variables. These variables are measured by research instruments so that the data consisting of the numbers can be analyzed based on statistical procedures. To facilitate the research, the SPSS program is used.

\section{RESULT AND DISCUSSION}

Respondent's Characteristic. Based on the results of data on 120 respondents it can be seen that the most respondents are male that is as much as 69 respondents $(57.5 \%)$, while the rest of women are 51 respondents $(42.5 \%)$. In addition it can be seen that the age of respondents most aged 21-30 years are 95 respondents $(79.2 \%)$, then aged $31-40$ years as many as 20 respondents (16.7\%), while the remaining age $41-50$ years as many as 5 respondents $4.2 \%$ ).

As for the highest education, it was found that most respondents were educated by $\mathrm{S} 1$, that is 78 respondents $(65.0 \%)$, followed by Diploma 3 with 24 respondents $(20.0 \%)$, third was SMA (Senior High School) with 10 respondents $(8.3 \%$ ), and the rest were educated S 2 with 8 respondents $(6.7 \%)$. In addition, it can be seen that the average occupation of respondents as private employee is 90 respondents $(75.0 \%)$, secondly there are entrepreneurs with 13 respondents $(10,8 \%)$, in third there are students with 8 respondents $(6,7 \%)$, in the fourth there is a civil servant with 7 respondents $(5.8 \%)$ and the rest as housewives with 2 respondents $(1.7 \%)$. 
For the respondents' income, it is known that the highest income respondents are 7,1 - 10 million 52 respondents $(43,3 \%)$, secondly with income more than 10 million there are 49 respondents $(40,8 \%)$, third with income $4-7$ million as many as 12 respondents $(10.0 \%)$, and the remaining income below 4 million as many as 7 respondents $(5.8 \%)$. For the data of the year of purchase, it can be seen that the most respondents are purchases in 2015 that is as much as 76 respondents (63.3\%), while the rest buy in 2016 as many as 44 respondents $(36.7 \%)$.

\section{Validity Test and Realibility Test}

Table 2. Validity Test and Realibility Test

\begin{tabular}{|c|c|c|c|c|c|c|c|c|c|c|c|}
\hline Variabel & Pertanyaan & $\begin{array}{c}\text { Nilai } \\
\text { Validitas }\end{array}$ & Kesimpulan & $\begin{array}{c}\text { Cronbsch's } \\
\text { Alpha }\end{array}$ & Kesimpulan & Variabel & Pertanyaan & $\begin{array}{c}\text { Nilai } \\
\text { Validitas }\end{array}$ & Kesimpulan & $\begin{array}{c}\text { Cronbsch's } \\
\text { Alpha }\end{array}$ & Kesimpulan \\
\hline \multirow{5}{*}{$\begin{array}{l}\text { Kualitas } \\
\text { Produk }\end{array}$} & KP1 & 0,820 & Valid & \multirow{5}{*}{0,88} & \multirow{5}{*}{ Reliabel } & \multirow{5}{*}{ Promosi } & P1 & 0,725 & Valid & \multirow{5}{*}{0,87} & \multirow{5}{*}{ Reliabel } \\
\hline & KP2 & 0.644 & Valid & & & & $\mathrm{P} 2$ & 0,736 & Valid & & \\
\hline & KP3 & 0.797 & Valid & & & & $\mathrm{P} 3$ & 0,797 & Valid & & \\
\hline & KP4 & 0,714 & Valid & & & & $\mathrm{P} 4$ & 0,857 & Valid & & \\
\hline & KP5 & 0,794 & Valid & & & & $\mathrm{P} 5$ & 0,773 & Valid & & \\
\hline \multirow{5}{*}{ Harga } & H1 & 0,785 & Valid & \multirow{5}{*}{0,89} & \multirow{5}{*}{ Reliabel } & \multirow{5}{*}{$\begin{array}{l}\text { Keputusan } \\
\text { Pembelian }\end{array}$} & K.Pem1 & 0,809 & Valid & \multirow{5}{*}{0,87} & \multirow{5}{*}{ Reliabel } \\
\hline & $\mathrm{H} 2$ & 0,834 & Valid & & & & K.Pem2 & 0,793 & Valid & & \\
\hline & H3 & 0,798 & Valid & & & & K.Pem3 & 0,787 & Valid & & \\
\hline & H4 & 0,749 & Valid & & & & K.Pem4 & 0,839 & Valid & & \\
\hline & H5 & 0,718 & Valid & & & & K.Pem5 & 0,833 & Valid & & \\
\hline
\end{tabular}

Source: Results of data processed with SPSS ver. 23

\section{Normality Test}

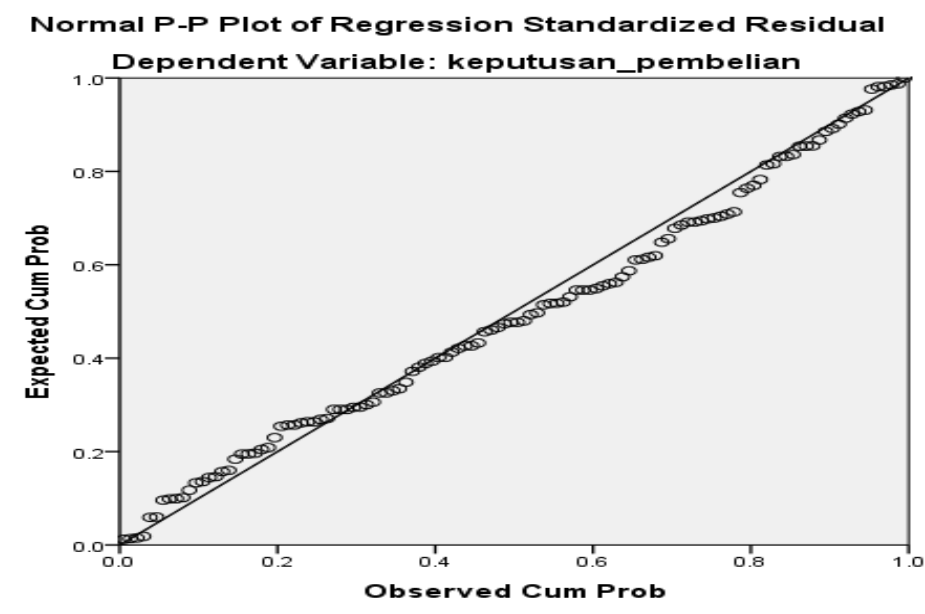

Figure 4. Normality Test

Source: Results of data processed with SPSS ver. 23

In Figure 4, it shows that the points spread around the line and follow the diagonal line, it can be concluded that the residual value generated from the regression is normal and satisfies the assumption of normality. 


\section{Heterocedasticity Test}

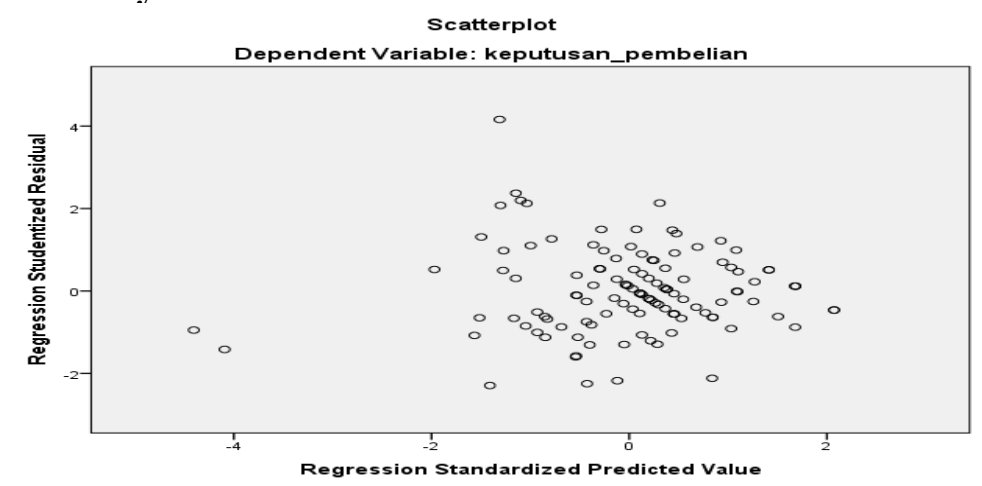

Figure 5. Test of Heterocedasticity

Source: Results of data processed with SPSS ver. 23

Figure 4 graph scatter plot on the purchase decision appear the dots that do not form a certain pattern. The scatter diagram above does not form a specific pattern. Thus it can be said that the regression does not experience heterocedasticity interference.

\section{Multicolonierity Test}

Table 3. Multicolonierity Test

\begin{tabular}{|c|c|c|c|}
\hline \multicolumn{4}{|c|}{ Coefficients ${ }^{a}$} \\
\hline \multirow[b]{2}{*}{ Model } & & \multicolumn{2}{|c|}{ Collinearity Statistics } \\
\hline & & Tolerance & VIF \\
\hline & $\begin{array}{l}\text { Kualitas_p } \\
\text { roduk }\end{array}$ & & 2.249 \\
\hline & harga & .465 & 2.149 \\
\hline & promosi & .373 & 2.682 \\
\hline
\end{tabular}

a. Dependent Variable:

Source: Results of data processed with SPSS ver. 23

From Table 3. it can be seen that the VIF value is smaller than 10 and the tolerance is greater than 0.1 so it can be concluded that there is no multicolonierity or high correlation between independent variables.

\section{Multiple Linear Analysis Test}

Table 4. Multiple Linear Regression

\begin{tabular}{|l|c|}
\hline & $\begin{array}{c}\text { Standardized } \\
\text { Coefficients }\end{array}$ \\
\hline (Constant) & 1.956 \\
\hline Kualitas Produk & .462 \\
\hline Harga & .239 \\
\hline Promosi & .256 \\
\hline
\end{tabular}

Source: Results of data processed with SPSS ver. 23 
Table 4. shows the multiple linear regression equation as follows

$$
\mathrm{Y}=1,956+0,462 \mathrm{X}_{1}+\mathbf{0 , 2 3 9} \mathrm{X}_{2}+0,256 \mathrm{X}_{3}+\mathrm{e}
$$

The regression equation $\mathrm{Y}=1,956+0.462 \mathrm{X} 1+0,239 \mathrm{X} 2+0,256 \mathrm{X} 3$ illustrates that independent variable (product) quality X1, Price (X2), Promotion (X3), in the regression model can be stated if one independent variable change by 1 (one) and the other constant, then the dependent variable changes (dependent) Purchase decision (Y) is equal to the value of coefficient (b) of the value of the independent variable. The constant $(\alpha)$ of 1.956 gives the sense that if product quality (X1), Price (X2), Promotion (X3), simultaneously or together does not change or equal to zero (0) 1,956 units.

\section{Coefficient of Determination Test (R2)}

Table 5. Coefficient of Determination

\begin{tabular}{lcrrrr}
\hline Model & R & R Square & $\begin{array}{l}\text { Adjusted R } \\
\text { Square }\end{array}$ & $\begin{array}{l}\text { Std. Error of } \\
\text { the Estimate }\end{array}$ & $\begin{array}{l}\text { Durbin- } \\
\text { Watson }\end{array}$ \\
\hline 1 & $.826^{\mathrm{a}}$ & .682 & .673 & 2.04896 & 2.280 \\
\hline
\end{tabular}

Source: Results of data processed with SPSS ver. 23

In Table 5 the correlation value between product quality variable (X1), price (X2), promotion $(\mathrm{X} 3)$ to purchase decision $(\mathrm{Y})$ is 0,673 . It can be concluded that there is a correlation or strong relationship between product quality, price, and promotion variables with purchase decision because Adjusted $\mathrm{R}$ square value is above 0.5.

\section{F Test}

Table 6. Test

\begin{tabular}{|c|c|c|c|c|c|c|}
\hline Model & & $\begin{array}{c}\text { Sum of } \\
\text { Squares }\end{array}$ & df & $\begin{array}{l}\text { Mean } \\
\text { Square }\end{array}$ & $\mathrm{F}$ & Sig. \\
\hline 1 & $\begin{array}{l}\text { Regressio } \\
\mathrm{n} \\
\text { Residual } \\
\text { Total }\end{array}$ & $\begin{array}{r}1042.795 \\
486.997 \\
1529.792\end{array}$ & $\begin{array}{r}3 \\
116 \\
119\end{array}$ & $\begin{array}{r}347.598 \\
4.198\end{array}$ & 82.796 & $.000^{\circ}$ \\
\hline
\end{tabular}

Source: Results of data processed with SPSS ver. 23

In Table 6. it can be seen that the Sig number in the ANOVA Table is 0.000 . This value is smaller than the set rate of 0.05 . From that point, based on the test criteria, it can be concluded that the variable of Product Quality, Price, and Promotion together influence to the purchasing decision.

Table 7. T Test

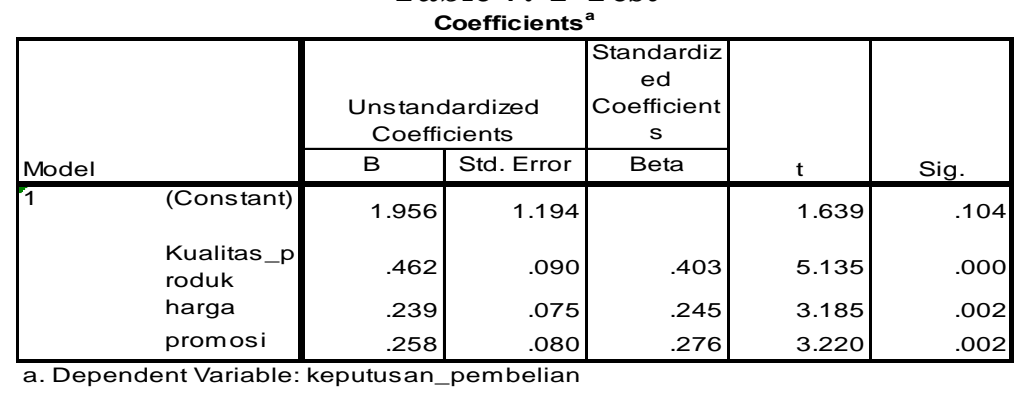

Source: Results of data processed with SPSS ver. 23 
In Table 5.5 it can be seen that the sig number for the product quality variable has sig 0,000 , the price variable has sig 0.002 , and the promotion variable has sig 0.002 , where all of these variables have sig $<0,05$ which means that all variables have significant influence on the decision purchase.

The Influence of Product Quality on Purchase Decision. The effect of product quality to customer based on the result of $t$ test result data for product quality variable which has value of 0.000. So it can be concluded that there is a significant positive influence between the quality of purchasing decisions, the better the quality of products received by consumers, it will cause thatthe purchase decision is on consumers. This research is in line with the results of previous research (Krestiawan Wibowo Santoso dkk, 2013) that product quality has a significant effect on purchasing decision. The researchers found that many respondents said they did not agree that the fuel consumption of HONDA HR-V is economical, it can be seen in the question KP2 with the results get the lowest average value of 3.54. In addition to the researcher getting voice of customer, the width of HONDA HR-V is not wider than TOYOTA RUSH, it proves that Indonesian consumer behavior in deciding the purchase of one of the most powerful factors is the features of the car offered.

Price Influence on Purchase Decision. Based on the result of data analysis, it is explained that the result of $T$ test for price variable has value 0,002 . So it can be concluded that the price is a variable that significantly influence the purchase decision, the more appropriate price given to consumers, it will cause consumers decide to buy it. This study is in line with previous research results (Nabila H Zhafira et al, 2013, Sagala et al, 2014) that prices have a significant effect on purchasing decisions.

The Influence of Promotion on Purchase Decision. Based on the result of data analysis, it is explained that the result of $\mathrm{T}$ test for price variable has value 0,002 . So it can be concluded that promotion is a variable that significantly influence purchasing decisions, the more frequently promotional activities undertaken, then the level of market awareness of the product will increase, and will further stimulate consumers to make purchasing decisions. This research is in line with previous research results (Ahmad Muanas, 2014, Nabila H Zhafira et al., 2013) that promotion has a significant effect on purchasing decisions.

\section{CONCLUSION}

1. From the results of multiple regression analysis that independent variables, namely product quality, price and promotion have a significant influence on purchasing decisions HONDA HR-V. Thus, in this case it can be said that if the quality of the product and the price offered after the consumer's perception and promotion shown by the company on the product being sold is also good, it will lead to increased purchasing decisions at the company. In this case the product quality plays a greater role than price and promotion in the formation of purchasing decisions.

2. The effect of product quality, price and promotion on purchasing decision is $67,3 \%$, and there are still $32,7 \%$ other variables influencing purchasing decision of HONDA HR-V. (but in this study, there is no research on these factors or variables but based on 
the theory it could be caused by the factor of brand image, word of mouth, quality of service, level of satisfaction, and consumer loyalty)

3. Overall assessment of the respondents on product quality of HONDA HR-V is good and positive. The highest average rating on product quality at HONDA HR-V is contained in the statement "HONDA HR-V has a product design in accordance with current market trends". While the lowest average rating is "HONDA HR-V has an economical fuel consumption", which in this case means consumers are doubtful or not sure about it.

4. Overall assessment of respondents on prices of HONDA HR-V is good and positive. The highest average valuation of the price on HONDA HR-V is contained in the statement "The prices of HONDA HR-V compete with other brands". While the lowest average rating is "Price of HONDA HR-V is in accordance with my wishes", which in this case means consumers are doubtful or not sure about it.

5. Overall assessment of respondents on promotion of HONDA HR-V is good and positive. The highest rating on HONDA HR-V promotion is in the statement "I feel the HONDA HR-V salespeople are friendly in providing the information available". While the lowest scoring average is "I feel the coupon of every car purchase HONDA HR-V affects me in making a purchase", which in this case means the consumer is doubtful or unsure about it.

6. Overall purchase decisions formed among HONDA HR-V consumers are good and positive. The highest average rating can be seen on the most prominent HONDA HR$\mathrm{V}$ purchase decision, which is stated in the statement "I am evaluating some existing car brands". While the lowest average rating is "I am looking for information from many sources about HONDA HR-V", which means that consumers judge the ordinary about it.

\section{Suggestions}

1. Product Quality. Based on the results of this study, it is recommended that HONDA should always pay attention to the quality of existing products, by providing futuristic models later in the presence of facelift HONDA HR-V products.

2. Price. Based on the results of this study, that price gives the least effect. Therefore it is advisable for HONDA to be able to provide additional discount programs, or in the form of a lease program with low installment interest or long repayment period.

3. Promotion. Based on the results of this study, the promotional activities undertaken by HONDA HR-V in the form of advertisements, exhibitions or exhibitions are sufficient to increase the market awareness of this product, therefore the activities that have been carried out continue to run and the number of broadcast should be increased .

\section{REFERENCES}

Ahmad Munas. (2014). "Pengaruh Kualitas Produk, Harga Dan Promosi Terhadap Keputusan Pembelian Mobil Buana INDOMOBIL TRADA". Jurnal Ilmu \& Riset Manajemen, 3 (12).

Ali Ismajli, Mr.Sc., Saranda Kajtazi, Ejup Fejza, (2013). The Impact Of Promotional Activities On Purchase Decision Making: "A Case Study Of Brands Bonita And Rugove -Water Bottled Producers ”. European Scientific Journal. 9 (31), ISSN: 1857 -7881 . 
Angelina Rares, Rotinsulu Jopie Jorie. (2015). "Pengaruh Harga, Promosi, Lokasi, Citra Merek Dan Kualitas Produk Terhadap Keputusan Pembelian Konsumen Di Toko Bengkel Gaoel Manado Town Square”. Jurnal EMBA. 3 (2), 592-604.

Assauri, Sofjan. (2009). Manajemen Pemasaran Dasar, Konsepdan Strategi, Edisi Pertama. Jakarta: Raja GrafindoPersada.

Buchari, Alma. (2006). Pemasaran dan Pemasaran Jasa. Bandung: Alfabeta.

Christian Sagalaet al. (2014). Influence of Promotional Mix and Price on Customer Buying Decision toward Fast Food sector: A survey on University Students in Jabodetabek (Jakarta, Bogor, Depok, Tangerang, Bekasi) Indonesia". International Journal of Scientific and Research Publications, 4 (1), ISSN 2250-3153.

Ety Rochaety. (2009). Metodologi Penelitian Bisnis. Jakarta: MitraWacana Media.

Ghozali, I. (2013). AplikasiAnalisis Multivariate Dengan Program. EdisiKetujuh.

Semarang: Badan Penerbit Universitas Diponogoro.

Ghozali, Imam. (2011). AplikasiAnalisis Multivariate dengan Program IBM SPSS19. Semarang: Badan Penerbit Universitas Diponegoro.

Imam Heryanto. (2015). "Analisis Pengaruh Produk, Harga, Distribusi, Dan Promosi Terhadap Keputusan Pembelian Serta Implikasinya Pada Kepuasan Pelanggan”. Jurnal Ekonomi, Bisnis, \& Entrepreneurship. 9 (2), 80-101

Kotler, P., \& Armstrong, G. (2008). Dasar-Dasar Pemasaran. Edisi Sembilan. Jilid 1, Dialihbahasakan Oleh Alexander Sindor. Jakarta: Prenhalindo.

Kotler, Philip. (2008). Strategi Pemasaran. Jakarta:Prenhalindo.

Krestiawan Wibowo Santoso. (2013). Pengaruh Kualitas Produk, Harga Dan Promosi Terhadap Keputusan Pembelian Permen Tolak Angin Di Semarang, Diponegoro Journal Of Social And Politic. Hal 1-10.

Leow Chee Seng, Zahari Husin. (2015). "Product and Price Influence on Cars Purchase Intention in Malaysia". International Research Journal of Interdisciplinary \& Multidisciplinary Studies (IRJIMS). I (VII), 108-119

Mahmud I. Nour, mohammad salamh almahirah, Sultan Mohammed Said, Sultan Freihat. (2014). "The Impact of Promotional Mix Elements on Consumers Purchasing Decisions". International Business and Management CS Canada, 8 (2), 143-151.

Mohamed Dawood Shamout. (2016). "The Impact of Promotional Tools on Consumer Buying Behavior in Retail Market”. International Journal of Business and Social Science. 7 (1). ISSN: 2219-1933.

Nabila H Zhafira et al. (2013). "The Analysis Of Product, Price, Place, Promotion And Service Quality On Customers' Buying Decision Of Convenience Store: A Survey Of Young Adult In Bekasi, West Java, Indonesia”, International Journal of Advances in Management and Economic. 2 (6), ISSN: 2278-3369.

Owusu Alfred. (2013). "Influences of Price And Quality On Consumer Purchase Of Mobile Phone In The Kumasi Metropolis In Ghana A Comparative Study". European Journal of Business and Management. 5 (1), ISSN 2222-1905.

Purwati, Heri Setiawan, Rohmawati. (2012). "Pengaruh Harga dan Kualitas Produk Terhadap Kepututsan Pembelian Motor Honda Matic Beat (Studi Kasus Pada PT. Nusantara Solar Sakti) ’. Jurnal Ekonomi Dan Informasi Akuntansi (Jenius), 2 (3).

Rambat, Lupiyoadi, dan A. Hamdani. (2006). Manajemen Pemasaran Jasa. Edisi Kedua. Jakarta: Salemba Empat.

Sugiyono. (2009). Metode Penelitian Kuanittatif dan Kualitatif. Bandung: CV. Alfabeta. 
Suryani, Tatik. (2008). Perilaku Konsumen: Implikasi pada Strategi Pemasaran. Edisi 1. Yogyakarta: Grahallmu.

Swastha, Basu dan Irawan. (2005). Manajemen Pemasaran Modern. Yogyakarta: Liberty. Swastha, Basu dan Handoko, Hani. (2010). ManajemenPemasaran: Analisa dan Perilaku Konsumen. Yogyakarta: BPFE.

Taufik Rachim, Iwan Setiawan. (2014). "The Effects of Product Attributes and Pricing Policy to Netbook Purchase Decision: (Case Study of Universitas Widyatama Students). International Journal of Science and Research (IJSR)”. 3 (4), ISSN: 2319-7064

Tjiptono, Fandy. (2007). StrategiPemasaran. EdisiKedua. Yogyakarta : Andi. 